\title{
Response to Commentaries
}

\section{John M Corkery, np-SAD Programme Manager}

Dr Klein's assertions about the origins of registers on drug-related death are inaccurate, probably due to misunderstanding some of the fundamental epidemiological indicators of drug misuse, including mortality. Whilst it is true that there were many deaths involving the misuse of opium, typically as laudanum, in the nineteenth century, the need for civil registration of deaths in the UK introduced in 1864 was recognition of the need to monitor mortality due to fatal epidemic outbreaks of diseases such as typhoid, cholera, dysentery and smallpox. The UK was the first nation to commence recording drug-related deaths per se with the setting up of the Home Office Addicts Index in the 1920s, and the first statistics from this source were published by the League of Nations in the early 1930s. Publication of statistics relating to the death of these addicts continued until 1997 (Corkery 1997). The national programme on Substance Abuse Deaths (np-SAD) was set up in 1997, in part, to continue to actively monitor deaths of addicts and deaths related to drug misuse as well as to provide a centre of expertise on epidemiology relating to this phenomenon.

There is a misrepresentation of some of the information in this commentary. The case criteria established by np-SAD in 1997 have not changed, neither have the Programme's objectives or raison d'être (Ghodse et al, 2010). There has been no 'mission creep' as Klein describes in respect of the Programme. Within the scientific community as a whole, especially in Europe, there has been a wider recognition of the role which the abuse of psychoactive substances has in causing morbidity and premature mortality. The Programme actively participates in these surveillance and research activities.

The reason for writing this paper about 'khat-related' deaths is to provoke a discussion about the nature of the links between the use of a psychoactive substance and mortality in all its shapes and forms. This is not an attempt to increase the need for special mortality registers by widening case definitions, but a vehicle to demonstrate the broad spectrum of associations, including causality, between activities related to the use of khat and deaths. This paper uses concrete examples reported to $\mathrm{np}-\mathrm{SAD}$ to illustrate some of the consequences of khat consumption, as has been done in previous papers dealing with other substances (Schifano et al, 2003; Oyefeso et al, 2006; Schifano et al, 2008). Scientific rigour has not been ignored in collecting and reporting these deaths; we have not attempted to shoe-horn individual cases into categories which support a particular view-point with regard to the status of khat.

The Programme's objectives are primarily to inform the debate on substance use and misuse. This is done in a non-partisan, apolitical, and as objective a manner as possible. We let the facts speak for themselves. We do not hold any particular view about substance use - other than to reduce and prevent associated deaths. The Programme, like the INCB, merely brings information to the notice of policy-makers and leaves them to make their own judgements. If commentators wish to see our research as politically motivated - that is up to them. They should also be open about their own perspectives and views; there is no embarrassment in stating what one's stance is and why it is held.

np-SAD believes there are potentially serious consequences that can result from the use of khat. These need to be aired, especially when there are constituencies that may wish to avoid mentioning such eventualities, as that serves their purposes more than those who might suffer as a consequence of lack of information - or indeed misinformation. These issues need to be heard and discussed in an informed way. As Klein has co-written in a Briefing just published by the EMCDDA (2011) "khat research is in its infancy and there is little robust information on the subject".

The need to place khat-related deaths in context is rightly pointed out by Singleton in her commentary, and her piece helps to do that. Our paper does not seek to overstate the risk of mortality from khat but highlight the potential for death by reference to actual specific instances, rather than ignoring the sad loss of lives from what is often put forward by some constituencies as benign and harmless.

This is also true of former 'legal highs' such as mephedrone. The media interest in alleged fatalities in the UK due its use was often 'over the top', but may have helped in preventing some deaths. In the event, np-SAD is currently aware of at least 110 alleged deaths, of which about 80 have been 
confirmed by toxicological investigation as having consumed mephedrone prior to death. To date, legal inquiries (inquests, etc) have been completed for nearly 50 of these cases; in half of these, mephedrone was implicated in death; it was given as sole cause of death in 8 cases, suggesting the acute toxicity potential of the substance.

With regard to khat, mephedrone or other novel psychoactive chemicals that emerge as recreational substances, np-SAD does not seek to label such substances as 'killers', but to put on record instances of fatalities where (a) these drugs have been found, providing evidence of their use and epidemiology, and (b) where they have caused or contributed to death. This helps in providing pieces of the jigsaw so that policy-makers can decide what the picture on the lid might look like.

\section{References}

Corkery JM. (1997) Statistics of Drug Addicts notified to the Home Office, United Kingdom, 1996, Home Office Statistical Bulletin 22/97; Area Tables; Scotland Tables. 14 October 1997. London: Home Office Research and Statistics Directorate.

Ghodse, H., Corkery, J., Ahmed, K., Naidoo, V., Oyefeso, A. and Schifano, F. (2010). Drug-related deaths in the UK: Annual Report 2010. Drug-related deaths reported by Coroners in England, Wales, Northern Ireland, Guernsey, Jersey and the Isle of Man; Police forces in Scotland; \& the Northern Ireland Statistics and Research Agency - Annual Report January-December 2009. London: International Centre for Drug Policy, St George's University of London. 24 August 2010.

Odenwald, M., Klein, A. and Warfa, N. (2011). Khat use in Europe: implications for European policy. Drugs in focus 21. 4 July 2011. Lisbon, Portugal: European Monitoring Centre for Drugs and Drug Addiction. Available at:

http://www.emcdda.europa.eu/attachements.cfm/att 137392 EN TDAD11001ENC WEB.pdf. Accessed on 4 July 2011.

Oyefeso A, Schifano F, Ghodse H, Cobain K, Dryden R, Corkery J. 'Fatal injuries while under the influence of psychoactive drugs: a cross-sectional exploratory study in England'. BMC Public Health. 2006 Jun 6;6:148. PubMed PMID: 16756659; PubMed Central PMCID: PMC1523208.

Schifano F, Corkery J, Oyefeso A, Tonia T, Ghodse AH. 'Trapped in the "K-hole":overview of deaths associated with ketamine misuse in the UK (1993-2006)'. J Clin Psychopharmacol. 2008 Feb;28(1):114-6. PubMed PMID: 18204359.

Schifano F, Oyefeso A, Webb L, Pollard M, Corkery J, Ghodse AH. 'Review of deaths related to taking ecstasy, England and Wales, 1997-2000'. BMJ. 2003 Jan 11;326(7380):80-1. PubMed PMID: 12521971; PubMed Central PMCID: PMC139936. 